\title{
ARTICLE
}

\section{The Rise and Fall of the Tribunal of the Southern African Development Community: Implications for Dispute Settlement in Southern Africa}

\author{
Erika de Wet $^{1}$
}

\begin{abstract}
The article explores the impact of Zimbabwe's land reform policies since the turn of the century on the Southern African Development Community (SADC), notably its central issue instrument for dispute settlement, namely the SADC Tribunal. In the landmark ruling of Campbell and Others $v$ Zimbabwe the SADC Tribunal found the expropriation of agricultural land without compensation to be discriminatory and in violation of the SADC Treaty. While the Decision was rejected by Zimbabwe it was successfully implemented in South Africa, resulting inter alia in the attachment of Zimbabwean property situated in Cape Town. However, the Campbell Decision met with extensive political resistance throughout the SADC region which ultimately lead to the SADC Tribunal's suspension in 2012. The article analyses in particular the jurisdiction of the SADC Tribunal to entertain human rights disputes; whether the Tribunal was legally constituted; as well as the manner of enforcement of the Tribunal's decisions in the domestic legal orders of member States. In addition the article reflects on the consequences of the suspension of the SADC Tribunal for dispute settlement in Southern Africa.
\end{abstract}

\section{INTRODUCTION}

The Southern African Development Community (SADC) was formally established in 1992 in Windhoek, replacing the Southern African Development Coordination Conference (SADCC) that was established by the so-called frontline States in 1980 in Lusaka. Whereas the SADCC had the purpose of pursuing economic policies that would reduce their dependency on apartheid South Africa, SADC had the ambitious goal of developing a regional economic community in which post-apartheid South Africa was subsequently integrated. ${ }^{2}$ The SADC is currently

\footnotetext{
${ }^{1}$ Biur, LLB, LLD (University of the Free State); LLM (Harvard); Habilitationsschrift (Zurich); Co-Director of the Institute for International and Comparative Law in Africa and Professor of Public International Law, University of Pretoria (South Africa); Professor of International Constitutional Law, University of Amsterdam (The Netherlands). Email: erika.dewet@up.ac.za.

${ }^{2}$ Treaty of the Southern African Development Community ('the 1992 Treaty') (opened for signature 17 August 1992) available at <http://www.sadc-tribunal.org/docs/Treaty.pdf $>$ accessed 28 November 2012.
} 
composed of 14 member States including Angola, Botswana, the Democratic Republic of Congo (DRC), Lesotho, Madagascar (currently suspended until the constitutional order has been restored), ${ }^{3}$ Malawi, Mauritius, Mozambique, Namibia, South Africa, Swaziland, Tanzania, Zambia and Zimbabwe.

Article 5(1)(a) of the South African Development Community Treaty (the SADC Treaty $)^{4}$ places economic growth and development at the top of the SADC objectives. In addition, Article 4 (Principles) and Article 6 (General Undertakings) of the SADC Treaty indicate that the objective of economic integration has to be achieved through the guarantee of democracy, human rights and the rule of law. Article 4(c) obliges the organization and its member States to act in accordance with human rights, democracy and the rule of law. Article 6(2) further determines that the SADC and its member States 'shall not discriminate against any person on grounds of gender, religion, political views, race, ethnic origin, culture, ill health, disability, or such other ground as may be determined by the Summit'. These rather cursory references to human rights and the rule of law in Articles 4(c) and 6(2) triggered a series of highly controversial cases pertaining to the expropriation of agricultural land in Zimbabwe before the SADC's judicial organ (the Tribunal).

The Tribunal was established by Article 16(1) and (2) of the SADC Treaty, while the details of its composition, competencies and procedures were regulated in a separate Protocol on the Tribunal that was adopted on 7 August 2000 and entered into force on 14 August 2001. The Protocol provided the Tribunal with substantive jurisdiction over all disputes and all applications referred to it in accordance with the SADC Treaty and the Protocol on the Tribunal concerning the interpretation and application of the Treaty; the interpretation, application or validity of the Protocols; all subsidiary instruments adopted within the framework of the SADC and acts of the SADC institutions; as well as over all matters provided for in any other agreements that member States may conclude among themselves or within the Community and that confer jurisdiction on the Tribunal. ${ }^{5}$ As far as its personal jurisdiction is concerned, the Tribunal had jurisdiction over disputes between States as well as between natural or legal persons and States, subject to the requirement of the exhaustion of local remedies. ${ }^{6}$ The Tribunal also had exclusive jurisdiction in disputes between organs of the Community, or between Community personnel and the Community. ${ }^{7}$

\footnotetext{
${ }^{3}$ Communique of the Extraordinary Summit of SADC Heads of State and Government, Lozitha Royal Palace, Swaziland, (30 March 2009) para 16, available at <www.sadc.int/> accessed 28 November 2012. See also Cheryl Hendricks and Takwira Musavengana (eds), The Security Sector in Southern Africa (Institute for Security Studies 2010) 12 .

${ }^{4}$ Consolidated Text of the Treaty of the Southern African Development Community ('the SADC Treaty'), (adopted 17 August 1992, amended August 2001) available at <http://www.sadc.int/documents-publications/ sadc-treaty/> accessed 28 November 2012.

5 Protocol on Tribunal and the Procedures Thereof, art 14(a) and (c) available at <http://www.sadc-tribunal .org/docs/Protocol_on_Tribunal_and_Rules_thereof.pdf> accessed 28 November 2012.

${ }^{6}$ ibid art 15(1) and (2). See also Karin Klazen, 'Towards a Southern African Development Community: The SADC Tribunal and Its Recent Cases' (2010) 2 Namibia Law Journal 148. The Tribunal has, however, made it clear that it is not competent to adjudicate in disputes involving only natural or juristic persons. See Albert Fungai Mutize et al v Mike Campbell (Pvt) Ltd and others Case No SADC (T) 8/2008 (30 May, 2008). However, it is questionable whether Mutize did indeed concern private parties; compare United People's Party of Zimbabwe v SADC and Others, Case No SADC (T) 12/2008 (14 August 2009). See also Oliver C Ruppel and Francois X Bangwamwabo, 'The SADC Tribunal: A Legal Analysis of Its Mandate and Role in Regional Integration' (2007) 8 Monitoring Regional Integration in Southern Africa Yearbook 187.

7 Protocol on Tribunal (n 5) arts 14 and 15. See also Ruppel and Bangwamwabo (n 6) 188, Klazen (n 6) 148.
} 
The nature of decisions of the Tribunal and the procedures for their enforcement are contained in Article 32 of the Protocol on the Tribunal. This article determines that decisions of the Tribunal shall be binding upon the parties to the dispute in respect of that particular case and enforceable within the territories of the States concerned. ${ }^{8}$ The law and rules of civil procedure for the registration and enforcement of foreign judgments in force in the territory concerned shall govern the enforcement of judgments. It is furthermore the obligation of member States to take all measures necessary to ensure execution of decisions of the Tribunal. Any failure by a State to comply with a decision of the Tribunal may be referred to the Tribunal by any party concerned. If the Tribunal established the existence of such failure, it shall report its finding to the Summit for the latter to take appropriate action. ${ }^{9}$

The Tribunal, with seat in Windhoek, Namibia, became operational in November 2005 and its establishment initially signalled the beginning of a new era in which Southern African States were willing to accept a limitation on their sovereignty through international judicial supervision. ${ }^{10}$ However, this era was short lived, as in practice the work of the Tribunal had already been suspended in August 2010, when the Summit ordered a review on the role, function and terms of reference of the Tribunal to be completed within a period of six months. ${ }^{11}$ At the time the Summit also failed to renew the terms of judges eligible for reappointment, as well as to fill vacancies on the Tribunal. This factor combined with an instruction to the Tribunal not to take on new cases during the review process effectively suspended the work of the Tribunal. ${ }^{12}$

In May 2011 the Summit extended this suspension for another year, while further determining that the Tribunal will not hear any more cases, whether new or existing. Once again judges whose terms were due to expire were not reappointed. The Summit also mandated the SADC ministers of justice and attorneys-general to begin the process of amending the Protocol on the Tribunal and submit a progress report in 2011, with the final report to be delivered in August 2012. ${ }^{13}$ On 18 August 2012 the Summit of Heads of State and Government, the SADC's supreme policy-making organ (the Summit), ${ }^{14}$ suspended the work of the Tribunal indefinitely and resolved that a new Protocol on the Tribunal should be negotiated and that its mandate should be confined to inter-State disputes. ${ }^{15}$

The reason for the Tribunal's suspension can be found in the series of cases pertaining to the expropriation of agricultural land in Zimbabwe which dominated the agenda of the Tribunal during the five years of its existence. Of the 19

\footnotetext{
${ }^{8}$ Protocol on Tribunal (n 5) art 32 reaffirms and elaborates on the SADC Treaty (n 4) art 16(5), which determines that: 'The decisions of the Tribunal shall be final and binding.'

${ }^{9}$ Protocol on Tribunal (n 5) art 32(1)-(4); Ruppel and Bangwamwabo (n 6) 199.

10 Ruppel and Bangwamwabo (n 6) 179-80.

11 Communique of the 30th Jubilee Summit of SADC Heads of State and Government, Windhoed, Namibia, 17 August 2010, para 32 <www.sadc.int/> accessed 28 November 2012. This review was executed by Lorand Bartels and became known as the Bartels Report, see n 30.

12 Laurie Nathan, 'Solidarity Triumphs over Democracy-the Dissolution of the SADC Tribunal', (2011) 12 Development Dialogue 131.

${ }^{13}$ Communiqué Extraordinary Summit, Heads of State and Government of the Southern African Development Community, Windhoek, Republic of Namibia, (20 May 2011) paras 6-8, available at $<$ www.sadc.int $/>$ accessed 28 November 2012 .

14 SADC Treaty (n 4) art 10(1).

15 Final Communiqué of the 32nd Summit of SADC Heads of State and Government Maputo, Mozambique, (18 August 2012) para 24, available at <www.sadc.int/> accessed 28 November 2012.
} 
decisions which the Tribunal handed down before its suspension, 11 concerned Zimbabwe. Of these decisions, eight were related to the claim of discriminatory expropriation of agricultural land which was initiated by Campbell and Others $v$ Zimbabwe. ${ }^{16}$

Two of the three remaining cases involving Zimbabwe also concerned the violation of human rights. In Luke Tembani $v$ Republic of Zimbabwe, ${ }^{17}$ the Applicant had been denied a fair hearing after the seizure of his mortgaged property, while in Gondo and Others $v$ Republic of Zimbabwe ${ }^{18}$ the Zimbabwean Government had refused to give effect to court orders of Zimbabwean domestic courts that provided relief for victims of violence, thereby denying their right to a remedy. The final Decision concerning Zimbabwe related to the exclusion of the United Peoples' Party of Zimbabwe from the power-sharing process in Zimbabwe that was mandated by the SADC during an Extraordinary Summit in March 2007. ${ }^{19}$

Of the remaining eight cases, five concerned internal employment disputes between the SADC and its employees. ${ }^{20}$ The remaining three decisions concerned a default judgment against the Democratic Republic of Congo for unlawful seizure of property; ${ }^{21}$ a denial of jurisdiction in a case involving deportation from Tanzania, due to lack of exhaustion of local remedies; ${ }^{22}$ and a condonation of a late filing of defence by the Government of Lesotho in a case concerning the cancellation and revocation of mineral leases. ${ }^{23}$

The subsequent sections of this article will analyse the reasoning of the Campbell case, the subsequent attempts to enforce the Decision in Zimbabwe and South Africa, as well as some of the legal implications of the suspension of the Tribunal. The analysis will focus in particular on the substantive jurisdiction of the Tribunal (and notably the extent to which it may entertain human rights disputes), whether the Tribunal was legally constituted, the manner of enforcement of the Tribunal's decisions in the domestic legal orders of member States and the consequences of the suspension of the Tribunal for dispute settlement.

\footnotetext{
${ }^{16}$ Campbell and Others v Zimbabwe (Merits), Case No SADC (T) 2/2007 (28 November 2008). The seven other decisions pertaining to the Campbell saga concerned an interim ruling that preceded the ruling on the merits, various attempts at intervening in the case, as well as several decisions of non-compliance and/or contempt of court. Campbell $v$ Zimbabwe (Interim Ruling), Case No SADC (T) 2/2007 (17 December 2007); Fick and Others v Republic of Zimbabwe, CASE No SADC (T) 01/2010 (6 July 2012); Campbell $v$ Republic of Zimbabwe (Contempt of Court Ruling), Case No SADC (T) 03/2009 (5 June 2009); Campbell $v$ Zimbabwe Contempt of Court, Case No SADC (T) $11 / 08$ (18 July 2008); Nixon Chirinda and Others v Mike Campbell and Others, SADC (T) Case No 09/08 (17 September 2008); Gideon Stephanus Theron and 7 Others $v$ Zimbabwe (application to intervene in Campbell case) Case No SADC (T) 2/08 (28 March 2008); Albert Fungai Mutize and Others v Campbell and Others, SADC (T) Case No 8/08 (30 May 2008).

17 Luke Tembani v Republic of Zimbabwe, Case No SADC (T) 07/2008 (14 August 2009).

18 Gondo and Others v Republic of Zimbabwe, Case No SADC (T) 05/2008 (9 December 2010).

19 United People's Party of Zimbabwe v SADC and Others, Case No SADC (T) 12/2008 (11 June 2012). The Tribunal concluded that the exclusion of the Applicant was not contrary to the SADC mandate, as it was based on the objective criterion of not being represented in the National Assembly at the time.

${ }^{20}$ Angelo Mondlane v SADC Secretariat, Case No SADC (T) 07/2009 (21 October 2009); Clement Kanyama v SADC Secretariat, Case No SADC (T) 05/2009 (29 January 2010); Bookie Monica Kethusegile-furu v SADC Parliamentary Forum (Fudgement), Case No SADC (T) 02/2009 (11 June 2010); Bookie Monica Kethusegile-furu v SADC Parliamentary Forum (preliminary objections), Case No SADC (T) 02/2009 (5 February 2010); Ernest Francis Mtingwi v SADC Secretariat, SADC (T) Case No 1/2007 (27 May 2008). See also Ruppel and Bangwamwabo (n 6) 182; Klazen (n 6) 149.

21 Bach's Transport (PTY) LTD v Democratic Republic of Congo, Case No SADC (T) 14/2008 (11 June 2010).

22 The United Republic of Tanzania $v$ Cimexpan (Mauritius) LTD and Others, Case No SADC (T) 01/2009 (11 June 2010).

${ }^{23}$ Swissbourgh Diamond Mines and Others $v$ The Kingdom of Lesotho, Case No SADC (T) 04/2009 (11 June 2010 ).
} 


\section{THE CAMPBELL SAGA}

The Campbell saga resulted from the Constitution of Zimbabwe Act No 17 of 2005, which determined that certain farmland designated in the Government Gazette was expropriated by the State without compensation and without any avenue for judicial review on the domestic level. ${ }^{24}$ Although Act No 17 did not explicitly refer to race, the impact of its expropriation mandate overwhelmingly affected white farm owners who formed the large majority of the approximately 4000 victims of forced removals from their land. ${ }^{25}$

Central to the dispute before the Tribunal were the obligations on member States in Article 4(c) of the SADC Treaty to respect the human rights, democracy and the rule of law, as well as the principle of non-discrimination guaranteed in Article $6(2)$ of the SADC Treaty. ${ }^{26}$ The case was therefore not about expropriation as such, but about the discriminatory manner in which the expropriation had been undertaken, as well as the fact that all domestic avenues for judicial review were excluded. In this context, it is important to keep in mind that the SADC Treaty does not guarantee the right to property, whereas it explicitly guarantees non-discrimination.

\section{A. The Competence of the Tribunal Pertaining to Human Rights Disputes}

Zimbabwe questioned the jurisdiction of the Tribunal on several grounds. Its first submission in this regard was that the Plaintiffs did not exhaust local remedies. The Tribunal, inter alia referring to the European Court of Human Rights (the ECtHR) and the African Commission on Human and Peoples' Rights (the African Commission), acknowledged that the principle of the exhaustion of local remedies was well established in the procedures of human rights bodies. However, it underscored that this condition did not apply where no domestic remedies were available or where they were ineffective. In the current case, the Zimbabwean Supreme Court itself confirmed that the jurisdiction of the courts was ousted in relation to the Applicants. As a result, the Tribunal decided unanimously that the domestic remedies requirement did not apply in this instance. $^{27}$

Zimbabwe further claimed that the Tribunal did not have jurisdiction in relation to human rights disputes. According to Zimbabwe, the human rights principles and objectives contained in Articles 4(c) and 6(2) of the SADC Treaty were not enforceable, as they did not spell out the benchmarks for measuring the conduct of member States in relation to human rights. These principles could only be enforced once a Protocol on human rights and land reform had been adopted and ratified by member States. Borrowing instead from human rights standards in

\footnotetext{
${ }^{24}$ See Constitution of Zimbabwe Amendment (No. 17) Act of 16 September 2005, s 16B(2)(b) and s 16B(30)(a) $<$ http://www.chr.up.ac.za/images/files/documents/ahrdd/zimbabwe/zimbabwe_constitution_amendment_2005.pdf $>$ accessed 24 November 2012. Farmers could be compensated only for improvements to the land.

25 See Ruppel and Bangwamwabo (n 6) 184.

${ }^{26}$ Consolidated SADC Treaty (n 4) art 6(2) determines that: 'SADC and member States shall not discriminate against any person on grounds of gender, religion, political views, race, ethnic origin, culture, ill health, disability, or such other ground as may be determined by the Summit'. See also Ruppel and Bangwamwabo (n 6) 183.

27 Mike Campbell (Pty) Ltd v Minister of National Security Responsible for Land, Land Reform and Resettlement, Case No SC 49/07 (22 February 2008). See also Admark Moyo, 'Defending Human Rights and the Rule of Law by the SADC Tribunal: Campell and Beyond' (2009) 9 African Human Rights Law Journal 601; See Campbell (Merits) (n 16) 19-21; also Ruppel and Bangwamwabo (n 6) 185.
} 
other treaties would amount to legislating by the Tribunal on behalf of member States. ${ }^{28}$

This argument was also unanimously rejected. According to the Tribunal, the adoption of a separate Protocol on human rights was unnecessary. Article 21(b) of the Protocol on the Tribunal mandated the Tribunal to develop its own jurisprudence, having regard to applicable treaties, general principles and rules of public international law. As a result it could rely on other relevant international instruments in order to clarify the meaning of the human rights concepts in the SADC Treaty. ${ }^{29}$

The Tribunal's arguments were convincing insofar as they confirmed that principles and objectives-depending on how they are formulated-can indeed constitute binding obligations. This is illustrated by inter alia Article 38(1)(c) of the Statute of the International Court of Justice that acknowledges 'the general principles of law recognized by civilized nations' as a binding source of international law. ${ }^{30}$ Moreover, Article 21(b) can be seen as a concretization of the principle of systemic integration which is contained in Article 31(3)(c) of the Vienna Convention on the Law of Treaties and also constitutes customary international law. It requires judicial bodies, when interpreting a treaty, to take into account any relevant rules of international law applicable in the relations between the parties. ${ }^{31}$ As a result, the Tribunal acted in accordance with international law when relying on human rights instruments ratified by Zimbabwe in order to determine the meaning of the concepts 'human rights' and 'rule of law' in Article 4(c). ${ }^{32}$ The same applies to the prohibition of discrimination contained in Article 6(2) of the SADC Treaty. ${ }^{33}$

An additional question which should have been considered by the Court is whether the principles contained in Articles 4(c) and 6(2) of the SADC Treaty were indeed intended to invest individuals in the member States with rights that could be directly invoked before the Tribunal. No drafting history of the SADC Treaty is available and the text of the SADC treaty leaves room for debate, as the relevant articles are phrased as State obligations and not as individual rights, which is usually the case with human rights treaties that guarantee enforceable rights. This question is separate from whether the content of the obligations contained in Articles 4(c) and 6(2) SADC Treaty can be determined by relying on human rights treaties which the relevant State had ratified and should also have been considered separately.

In deciding the merits of case, the Tribunal unanimously concluded that Article 4(c) of the SADC Treaty was violated, while a majority of four to one also found a violation of Article 6(2). ${ }^{34}$ The Tribunal determined that it is a fundamental

${ }^{28}$ Campbell (Merits) (n 16) 23; Moyo (n 27) 594.

29 Campbell (Merits) (n 16) 24; Moyo (n 27) 598.

30 Lorand Bartels, Review of the Role, Responsibilities and Terms of Reference of the SADC Tribunal (Final Report presented to the SADC member State Ministers of Justice and Attorneys-General Meeting on 14 and 15 April 2011)

${ }^{31}$ Bartels (n 30) 13-14, 21 suggests that art 21(b) is even broader than the rule expressed in the Vienna Convention on the Law of Treaties (adopted 23 May 1969), art 31(3)(c) available at <http://untreaty.un .org/cod/avl/ha/vclt/vclt.html > accessed 28 November 2012 .

32 Bartels (n 30) 10. Moyo (n 27) 93; Ruppel and Bangwamwabo (n 6) 195.

33 Bartels (n 30) 12, 21

34 The merits decision was preceded by a request for interim measures in terms of art 28 of the Protocol on Tribunal ( $\mathrm{n}$ 5). This request was directed at preventing the expulsion of Mr Campbell from his farm until the merits of the case had been decided. See also Ruppel and Bangwamwabo (n 6) 183. 
requirement of the rule of law that those who are affected by the law be heard before they were deprived of a right, interest or legitimate expectation. It stated that it is settled law that the concept of the rule of law embraced at least two fundamental rights, namely the right of access to the courts and the right to a fair hearing before an individual is deprived of a right. ${ }^{35}$ As this possibility had been ousted in relation to the contested expropriation, the Applicants had been denied the opportunity to seek redress in courts of law. ${ }^{36}$

In supporting its conclusion the Tribunal referred to decisions of the ECtHR and the Inter-American Court of Human Rights (IACtHR) as examples of persuasive authority. ${ }^{37}$ It further relied on Article $7(1)$ of the African Charter-an instrument to which Zimbabwe is a party - and which provides a right to appeal to competent national organs against acts violating a fundamental right. ${ }^{38}$ The Tribunal cited various decisions of the African Commission (including decisions against Zimbabwe), in which it criticized ouster clauses resulting in a denial of judicial review on the domestic level. ${ }^{39}$

When interpreting the prohibition of racial discrimination in Article 6(2) SADC Treaty, the Tribunal referred to four treaties to which Zimbabwe was a party and which outlawed racial discrimination, namely Article 2 of the African Charter, Article 2(1) of the International Covenant on Civil and Political Rights (ICCPR) and Article 2(2) of the International Covenant on Economic Social and Cultural Rights (ICESCR), as well as the Convention on the Elimination of all forms of Racial Discrimination. ${ }^{40}$ The Tribunal underlined that all of these instruments obliged Zimbabwe to respect, protect and promote the principle of non-discrimination and it must therefore prohibit and outlaw any discrimination based on the ground of race in its laws, policies and practices. ${ }^{41}$

The Tribunal subsequently concluded that the nature of the expropriation policy constituted indirect discrimination due to the fact that the differential treatment was directed at and almost exclusively felt by white farmers and did not serve a legitimate purpose. If the land reform had resulted in distribution of farmland to the poor, the landless and the marginalized, and had been accompanied by fair compensation, the purpose of the land acquisition by the government would have been legitimate and proportionate. However, as it stood, the land policy had an unjustifiable and disproportionate impact upon persons distinguished by race in violation of Article 6(2) of the SADC Treaty. ${ }^{42}$

35 Campbell (Merits) case (n 16) 26, 35.

36 Campbell (Merits) case (n 16) 24; see also Moyo (n 27) 595.

37 Golder v United Kingdom App No $4451 / 70$ (ECtHR, 21 February 1975) para 34; Philis v Greece App Nos 12750/ 87, 13780/88, 14003/88 (ECtHR, 27 August 1991) para 59; Fudicial Guarantees in States of Emergency, Advisory Opinion OC-9/87, Inter-American Court of Human Rights (6 October 1987) paras 24-5, 41; Campbell (Merits) (n 16) 27-9.

38 African Charter on Human and Peoples' Rights ('African Charter') (adopted 27 June 1981, entered into force 21 October 1986) art 7 (1)(a), available at <http://untreaty.un.org/cod/avl/ha/vclt/vclt.html > accessed $28 \mathrm{November}$ 2012.

39 Constitutional Rights Project, Civil Liberties Organisation and Media Rights Agenda v Nigeria (Comm No 140/94, 141/94 145/95) 1999, para 29; Zimbabwe Human Rights NGO Forum/Zimbabwe (Comm No 245) 2002, paras 171, 174; Campbell (Merits) (n 16) 32-4.

40 ibid $45-7$.

41 ibid $47-50$.

42 ibid 52-3; Moyo (n 27) 596. But see dissenting opinion of Judge Dr Onkemetse B Tshosa, Campbell (Merits) (n 16) 64-6. While in agreement on all other disputed issues, he dissented from the majority on whether there was a violation of SADC Treaty (n 4) art 6(2). He seemed to have attached less weight to the fact that the purpose of expropriation was not about addressing land injustices but to reward ZANU PF loyalists. Instead, he emphasized the historical context as a result of which most of the agricultural land was in the hands of white owners. Therefore, they 
From the Tribunal's reasoning, it is fair to conclude that the fact that only or overwhelmingly white farmers had been targeted by the land reform need not in itself have amounted to discrimination. In a country with a long colonial history, race and land ownership are closely intertwined, and any legislative policy designed to address historic inequities in land ownership will invariably adversely affect those who previously profited from systematic patterns of racial segregation. ${ }^{43}$ Decisive in this instance was the manner in which the land acquisition was executed. First, the designation of land for compulsory acquisition in the absence of criteria that, inter alia, considered the proper use of the land and allocated the land to ZANU PF supporters instead of to historically marginalized individuals or groups, ${ }^{44}$ exposed the arbitrary and unreasonable nature of the measures. ${ }^{45}$ Second, the unreasonableness of the measures was also underscored by the absence of adequate compensation as required by international law. ${ }^{46}$

\section{B. Questioning the Legality of the Tribunal}

Subsequent to the Campbell Decision, notably as of August 2009, Zimbabwe contended that the Tribunal was illegally constituted. It further proclaimed that it would neither appear before nor respond to any suit instituted before the Tribunal and that any prior or future decisions against Zimbabwe were null and void. ${ }^{47}$ In addition to articulating its position during political lobbying with member States, Zimbabwe also disputed the legality of the Tribunal before the High Court of Zimbabwe in Gramara (Private) Limited and Another $v$ The Republic of Zimbabwe. ${ }^{48}$ These proceedings were initiated by the Applicants in the Campbell case, subsequent to the Tribunal's favourable Decision on the merits, in an attempt to enforce the Decision in Zimbabwe. Although the High Court ultimately refused to enforce the Campbell Decision on grounds of public policy (that will be explored in Section II.C below), it rejected Zimbabwe's arguments pertaining to illegality of the Tribunal in no uncertain terms.

Zimbabwe's arguments centred on the submission that the Agreement Amending the Southern African Development Community Treaty (the Amending Agreement), ${ }^{49}$ signed on 14 August 2001, never entered into force because it was not ratified by a two-thirds majority as required by the SADC Treaty. As a result, the preceding version of the SADC Treaty was still in force, which determined in Article 22 that Protocols once adopted by the Summit had to

will necessarily be the ones predominantly affected by expropriation of agricultural land for resettlement purposes. They were therefore not targeted because they were white, but because they happened to be land owners. In addition, not all who were expropriated were white, as some black farmers were also affected.

43 Moyo (n 27) 602-3.

44 The Zimbabwean Government argued that the program was for the benefit of people who were disadvantaged under colonialism. However, this was unconvincing in light of the fact that the expropriated land mainly fell into the hands of the ruling party's supporters. See Campbell (Merits) (n 16) 43-4; 54.

${ }^{45}$ Moyo (n 27) 606. He noted that the favouring of ZANU PF supporters exposed also discrimination based on political orientation in addition to race. In some instance white farmers with close ties to ZANU PF retained their farms, whereas some black owners who supported the opposition were expropriated.

46 Campbell (Merits) (n 16) 56; see also Moyo (n 27) 607.

47 Letter of Justice Minister Patrick Chinamasa letter of 7 August 2009, cited in Moyo (n 27 ) 613.

48 Gramara (Private) Limited and Another v The Republic of Zimbabwe, Case No 5483/09 (26 January 2010).

49 Agreement Amending the Treaty of the Southern African Development Community ('the Amending Agreement') (adopted on 14 August 2001), available at <http://www.sadc-tribunal.org/docs/ AgreementAmendingTreaty.pdf $>$ accessed 28 November 2012. 
be subjected to signature and ratification by the member States. As far as the Protocol on the Tribunal was concerned, it was never ratified by Zimbabwe and the Tribunal therefore was not competent to hear any cases against it. ${ }^{50}$

This argument was based on a distortion of the amendment procedure for the 1992 Treaty. Whereas Article 41 of the 1992 Treaty indeed required a ratification by two-thirds of the signatory States before it could enter into force, a more simple procedure was foreseen for its amendment (once in force). Article 36(1) of the 1992 Treaty clearly stated that any amendment shall be adopted by a decision of three-quarters of all the Members of the Summit. ${ }^{51}$ In line with this requirement Article 21 of the Amending Treaty determined that it will enter into force on the date of its adoption by three quarters of all Members of the Summit. The High Court underscored that such a procedure for amendment was in keeping with Article 11 of the Vienna Convention of the Law of Treaties, which allows for the expression of consent to be bound by States in the manner which they prefer. ${ }^{52}$ The amendments foreseen in the Amending Treaty thus became operative immediately after its adoption by the Summit on 14 August $2001 .^{53}$

These amendments resulted in an amendment of what is now Article 16(2) of the revised SADC Treaty, in order to read that the Tribunal shall form an 'integral part' of the Treaty. ${ }^{54}$ Any doubt as to whether this reference was intended to exclude the Protocol on the Tribunal from the ratification procedure foreseen in Article 22 of the SADC Treaty for Protocols concluded by the member States was removed by the subsequent amendment of the Protocol on the Tribunal itself. ${ }^{55}$ On 3 October 2002 Articles 16 and 19 of the Agreement on Amending the Protocol on the Tribunal repealed Articles 35 and 38 of the Protocol of the Tribunal, which required ratification of the Protocol by two-thirds of the member States. This clearly removed the need for its ratification by any of the member States. Moreover, the preamble of this Agreement explicitly noted that the Protocol on the Tribunal entered into force upon the adoption of the Agreement Amending the Treaty of the Southern African Development Community at Blantyre on 14 August $2001 .^{56}$

The High Court of Zimbabwe also openly rebuked Zimbabwe for its ex post facto repudiation of the Tribunal's jurisdiction. It described it as untenable in light of the fact that the SADC Governments including Zimbabwe have actually applied the revised SADC treaty subsequent to the adoption of the Amending Agreement. One example concerned the establishment of and Zimbabwe's full participation in the Organ on Politics, Defence and Security Cooperation in terms of Articles 9

${ }^{50}$ Gramara case (n 48) 9. See also Nicole Fritz, "Up in Smoke: The SADC Tribunal and Rule of Law in the Region' (1 September 2012) No 11 South African Foreign Policy Initiative.

${ }_{51}$ Gramara (n 48) 10.

52 ibid 10; see Government of the Republic of Zimbabwe v Fick and Others ('Fick (SCA)') (657/11) [2012] ZASCA

122 (20 September 2012) paras 40-1.

53 Gramara (n 48) 11.

${ }^{54}$ SADC Treaty (n 4) art 16(2) determines that: 'The composition, powers, functions, procedures and other related matters governing the Tribunal shall be prescribed in a Protocol, which shall, notwithstanding the provisions of Article 22 of this Treaty, form an integral part of this Treaty, adopted by the Summit' (emphasis added).

${ }^{55}$ Zimbabwe submitted that the reference to 'integral part' does not per se remove the necessity for ratification, see Bartels (n 30) 79.

${ }^{56}$ Gramara (n 48) 12. See also Fick (SCA) (n 52) paras 36, 40; Nathan (n 12) 127-8. See also Bartels (n 30) 79. He suggests that the ratification procedures foreseen in art 22 were never intended to apply to the Protocol on the Tribunal. This provision concerns protocols in the areas of cooperation set out in art 21 , which do not include the topic of dispute settlement. The Protocol on the Tribunal was therefore always intended to have separate status under art 16 . 
and 9A of the SADC Treaty (as amended by Articles 9 and 10 of the Amending Agreement). The Court found it to be unsustainable for Zimbabwe to rely on those parts of the amended SADC regime which suited the county's interests, while rejecting simultaneously those features that were deemed to be politically inexpedient. ${ }^{57}$

The Court's criticism essentially confirmed the well-established international law principle that once States have treated a treaty as valid, they are later precluded from denying the opposite. ${ }^{58}$ In this context, it is important to keep in mind that Zimbabwe had signed both the Amending Treaty and the Agreement on the Amending of the Protocol. ${ }^{59}$ Like all other SADC members, it had also funded the Tribunal, participated in its judicial selection procedures (including the election of a Zimbabwean judge to the Tribunal) and, until 2009, appeared before the Tribunal. ${ }^{60}$

A final, related point is that a deviation from the procedure of Article 36(2) of the SADC Treaty during the adoption of the Amending Treaty would not affect the latter's legality, if acquiesced in by the member States. This Article determines that any SADC Member State may propose an amendment to the Executive Secretary for submission to the Council of Ministers for preliminary consideration, provided that the proposed amendment had been circulated to the other Member States with three months' notice. In relation to the Amending Treaty the proposal was not initiated by a member State, but by the SADC Secretariat. ${ }^{61}$ However, this deviation has been the consistent practice of SADC Member States in the context of amendments and accepted by all the member States at the time (including Zimbabwe). It is well accepted in international law that subsequent practice of States (and of an international organization), which is not entirely in accordance with procedure, but which is acquiesced in by all members, is legal and effectively amounts to an amendment of the treaty through practice. States that have acquiesced in such behaviour would be stopped from subsequently claiming that the deviating practice was illegal. ${ }^{62}$

\section{Enforcement of the Campbell Decision}

\section{(i) Enforcement in Zimbabwe}

Despite its recognition of the legality of the Tribunal and that Zimbabwe was bound by its decisions as a matter of international law, the Zimbabwean High

57 Gramara (n 48) 13.

58 Case Concerning the Arbitral Award made by the King of Spain on December 1906 (Honduras v Nicaragua) [1960] ICJ Rep 192, 209.

59 On the adoption of the Amending Treaty Angola was absent, while Mozambique was not present during the adoption of the Agreement on the Amending of the Protocol. See also Nathan (n 12) 128; See also MCC Mkandawire, 'The SADC Tribunal perspective on enforcement of judgments: state support and cooperation' (2010) 36 Commonwealth Law Bulletin 569; Werner Scholtz and Gerrit Ferreira, 'Much Ado About Nothing?: The SADC Tribunal's Quest for the Rule of Law Pursuant to Regional Integration' (2011) 71 Zeitschrift für ausländisches öffentliches Recht und Völkerrecht 355.

${ }^{60}$ Bartels (n 30) 77; Fick (SCA) (n 52) para 31.

61 Bartels (n 30) 75.

62 See Namibia (Advisory Opinion) [1971] ICJ Rep 16, para 22 as discussed in Bartels (n 30) 75. South Africa argued that a United Nations Security Council resolution was invalid because it had not been adopted by a concurring vote of the five permanent members, as required by art 27(3) of the UN Charter, two permanent members having abstained. The ICJ rejected this argument, based on the subsequent practice of the Security Council members coupled with the acquiescence in this practice of all UN members, including South Africa. 
Court refused to register the Campbell Decision. ${ }^{63}$ This apparently contradictory behaviour can be explained in part by the wording of Article 32(1) of the Protocol on the Tribunal. As indicated in Section I above, this Article determines that the judgments of the Tribunal shall be enforced in accordance with the rules of civil procedure for the registration and enforcement of foreign judgments in force in different member States. This means that a decision by an international tribunal is to be treated as a 'foreign judgment', which is traditionally understood to mean a judgment originating from within another State.

It is unusual for the treaties regulating the competencies of international tribunals to determine that their decisions shall be treated as 'foreign judgements' on the domestic level. Instead international decisions are usually to be treated as domestic judgments. ${ }^{64} \mathrm{~A}$ crucial difference is the fact that the recognition and enforcement of a 'foreign judgment' can be denied where it would result in a violation of public policy. The public policy exception is well established in the conflicts of law context, including where the enforcement of other national jurisdictions are at stake. However, it does not fit in a regime based on public international law such as the SADC regime, where States cannot use their domestic law as an excuse for not implementing their international obligations. ${ }^{65}$ In this instance, the binding character of the international obligations concerns the decisions of the Tribunal. ${ }^{66}$ The public policy exception implied by Article 32 of the Protocol on the Tribunal thus undermines the binding nature of the decisions of the Tribunal from the perspective of public international law, if it allows principles of domestic law to prevent the recognition and enforcement of foreign judgments. ${ }^{67}$

In the case of Zimbabwe the recognition and enforcement of foreign judgments are regulated by the Civil Matters (Mutual Assistance) Act [Chapter 8:02], as well as the common law which exist alongside the Act. ${ }^{68}$ Section 3, which extended the application of the Act to the judgments of those international tribunals specifically designated for the purpose of recognition and enforcement, did not include the Tribunal. ${ }^{69}$ As a result, the common law remained the only possible avenue through which the Tribunal's decisions could be recognized and enforced on the domestic level. ${ }^{70}$ Under the common law as applied in Zimbabwe at the time, a foreign judgment had to meet certain conditions in order to be recognized and enforced, one of which was that such enforcement may not result in a violation of public policy. ${ }^{71}$

The Court conceded that as a general rule, public policy would require Zimbabwe to give effect to its international treaty obligations and the binding Tribunals resulting from such obligations. By adhering to the Amending Treaty, the Amendment Agreement on the Protocol on the Tribunal and through its acceptance of the jurisdiction of the Tribunal, the Government of Zimbabwe had created an enforceable legitimate expectation both within and beyond the borders

63 Gramara (n 48) 5.

${ }^{64}$ Bartels (n 30) 53.

65 See VCLT (n 30) art 27; see also Moyo (n 27) 598.

66 See $\mathrm{n} 8$.

${ }^{67}$ Bartels (n 30) 53.

68 Gramara (n 48) 5-6.

${ }^{69}$ ibid 4.

70 ibid 5-6.

71 ibid 7 . 
of Zimbabwe that it would comply with the Tribunal's decisions. ${ }^{72}$ However, these factors had to be balanced against public policy challenges specific to the case at hand. These included the fact that a recognition and enforcement of the Tribunal's Decision in the Campbell case would be manifestly incompatible with the land reform programme foreseen in the Zimbabwean Constitution, which was also explicitly endorsed by the Zimbabwean Supreme Court. ${ }^{73}$ Under these circumstances a registration of the Campbell case would violate domestic public policy. ${ }^{74}$

It is suggested that in order to reconcile the public policy requirement with Zimbabwe's international law obligations, the High Court should have taken a different approach. It should have decided that Zimbabwean domestic public policy itself attached overriding weight to the country's international treaty obligations-including the binding judicial decisions resulting from such obligations. This would then have required the country to amend its legislation (including its Constitution) in order to give effect to its international obligations. However, the political realities in the country made such an outcome unlikely, if not impossible.

\section{(ii) Enforcement in other member States}

Subsequent to the unsuccessful registration and enforcement of the Campbell Decisions in Zimbabwe, both the merits Decision of 28 November 2008 and the non-compliance Decision of 5 June $2009^{75}$ were successfully registered in terms of Article 32(3) of the SADC Protocol in the South Africa High Court, with the purpose of confirming the cost order of the Tribunal against Zimbabwe. ${ }^{76}$ The domestic legal basis for registration was the Foreign Civil Judgments Act 32 of 1988 and the Recognition of Foreign Arbitral Awards Act 40 of 1977. The application for registration was not opposed by Zimbabwe which did not seem to take the process seriously until its effects were felt in the wake of the registration.

With the registration of the cost order in South Africa the way was paved for attaching Zimbabwean property for execution of the cost order. ${ }^{77}$ Subsequently, the High Court ordered the attachment of Zimbabwean property in Cape Town which was rented for commercial purposes at the time. ${ }^{78}$ This was done in accordance with section 14(3) of the South African Foreign States Immunities Act No 87 of 1981 ('Foreign States Immunities Act') which exempts property of a foreign State that is used for commercial purposes from immunity for the purposes of execution. ${ }^{79}$

72 ibid 13.

73 Campbell (n 27).

74 Gramara (n 48) 17-18.

75 See n 16.

76 Louis Karel Fick and Two Others Against the Government of the Republic of Zimbabwe; North Gauteng High Court, Pretoria, Case No 3106/07 (13 January 2010).

77 Scholtz and Ferreira (n 59) 355.

78 Republic of Zimbabwe $v$ Sherriff of Wynberg North and Others, Case No 2009/34015 (22 November 2011), unreported (on file with the author).

79 Sherriff of Wynberg ibid, 6-7. Other properties, although effectively unused by Zimbabwe for some time and not registered as a property which qualified for diplomatic immunity under the Diplomatic Immunities and Privileges Act 37 of 2001, was declared non-attachable. The Court accepted the argument of Zimbabwe that these properties were used for consular functions in Cape Town before and that these functions would resume as soon as the resource constraints which the country faced improved. 
This Decision of the High Court was ultimately confirmed on appeal by the South African Supreme Court of Appeal (SCA) in September 2012. The SCA further confirmed that Zimbabwe had forfeited any immunity which it may have enjoyed from the jurisdiction of South African courts by committing itself to the SADC Treaty and the Protocol on the Tribunal. ${ }^{80}$ The international law principle of sovereign immunity from jurisdiction before the domestic courts of a foreign State is incorporated in section 2 of the Foreign States Immunities Act. However, in accordance with section 3 of the Act, such immunity is forfeited through express waiver. The SCA underscored that all parties conceded that Article 32(3) of the Protocol on the Tribunal rendered decisions of the Tribunal enforceable in the territories of all member States. By its adoption of that article Zimbabwe clearly both waived any immunity it might otherwise have been entitled to claim from the jurisdiction of the courts of member States and agreed that orders of the Tribunal would be enforceable in those courts. ${ }^{81}$

In essence, the constellation of facts and circumstances of the registration and enforcement of the costs order were quite unique. South African courts were relying on domestic legislation that is predominantly used in the conflicts of law context to register a human rights verdict against a sovereign State in South Africa. This unique set of facts was enabled by the broad wording of Article 32(3) of Protocol on the Tribunal which determines that: 'decisions of the Tribunal shall be binding upon the parties to the dispute in respect of that particular case and enforceable within the territories of the States concerned...' This wording is open for an interpretation that allows enforcement in all SADC member States and not only in those which were party to the dispute. Similarly, Article 32(2) could be understood as referring to all member States when stating that: 'Member States and institutions of the Community shall take forthwith all measures necessary to ensure execution of decisions. ${ }^{82}$ This interpretation was also not disputed by any of the parties, including Zimbabwe.

It is unlikely that at the time of the adoption or amendment of the Protocol on the Tribunal any member State had given thought to the fact that the broad wording of Article 32 could result in the domestic enforcement of international human rights verdicts against a foreign State. Instead (and to the extent that they did ponder the consequences of the text of Article 32 at all), they most likely envisaged Article 32 to be used in commercial (trade) disputes. It therefore came as a surprise to many that Article 32 was used as a vehicle for providing a human rights remedy through the courts of third States, as opposed to the courts of the State against which the international decision was handed down. ${ }^{83}$

Finally, it is worth nothing that the SCA entirely disregarded the fact that the Tribunal had been suspended by the parties, at least in as far as the validity of the decisions of the Tribunal was concerned. The decisions handed down by the Tribunal before its suspension remained valid and enforceable. ${ }^{84}$

${ }^{80}$ Fick (SCA) (n 52) para 20.

81 ibid para 44 .

82 See also Bartels (n 30) 54.

83 Scholtz and Ferreira (n 59) 356.

84 The SCA also rejected Zimbabwe's assertion that the cost order may not be enforced as long as the Summit was considering 'appropriate action' in accordance with art 32(5) of the Protocol on Tribunal (n 5). It noted that art 32(5) of the Protocol required the Tribunal, once having found that a member state has failed to comply with its decision, to 'report its finding to the Summit for the latter to take appropriate action'. The 'action' contemplated by that article is action directed at compelling the offending state to mend its ways. The fact that Zimbabwe is attempting to convince 
(iii) The political response of the SADC member States to the Campbell saga Zimbabwe's rejection of the Tribunal's authority amounts to a rejection of Articles 16(5) of and 32(2) of the SADC Treaty, which confirms the binding nature of the Tribunal's decisions. The Tribunal itself does not have the competence to order remedies for non-compliance of its decisions, beyond determining that there had been non-compliance and reporting such a finding to the Summit. ${ }^{85}$ It is then up to the Summit, in accordance with Article 33(1) and 33(2) of the SADC Treaty, to impose sanctions on a country which persistently fails without good reason to fulfil obligations assumed under the SADC Treaty.

The language of Article 33 of the SADC treaty indicates that sanctions are not to be imposed lightly and should only follow persistent recalcitrant behaviour. Also, according to Article 33(1) sanctions 'may' be imposed, which indicates that this is a discretionary measure. ${ }^{86}$ However, in the case of Zimbabwe, there can be little doubt as to the persistency of the violation as reflected by Zimbabwe's public rejection of the Tribunal's decisions. ${ }^{87}$ Unfortunately, the SADC member States lacked the political will to take action against Zimbabwe. In fact, not only did the Summit refrain from public criticism or sanctions, but it also effectively rewarded Zimbabwe's recalcitrant behaviour by giving in to its demand that the Tribunal be suspended and the SADC Treaty amended in a manner that will in future only provide for inter-State complaints. ${ }^{88}$

From the perspective of treaty law, the manner in which the Tribunal was suspended is clearly illegal. Neither the SADC Treaty nor the Protocol on the Tribunal give the Summit the competence to suspend the activities of the Tribunal, and in order to invest the Summit with such a power, the Protocol would first have to be amended. ${ }^{89}$ The illegal suspension would also not have any legal effect on the validity of the decisions already handed down by the Tribunal, nor on their enforcement in the member States-as was clearly illustrated by the Decision of the South African SCA of September 2012.

\section{THE FUTURE OF DISPUTE RESOLUTION WITHIN THE SADC REGIME}

As far as the immediate future is concerned, dispute settlement within the SADC regime will be severely undermined given the fact that its principal organ for dispute settlement has been truncated. Thus far, all claims have been brought by

other member States to find an alternative solution does not affect the enforceability of the cost order. See Fick (SCA) (n 52) paras 46-7.

${ }^{85}$ See Protocol on Tribunal (n 5) art 32(4) and (5); see also Gramara (n 48) 4; Bartels (n 30 ) 43.

86 See also Ruppel and Bangwamwabo (n 6) 201.

87 See Bartels (n 30) 44 .

${ }^{88}$ SADC Treaty (n 4) art 33(2) does not indicate the nature of the sanctions that may be adopted by the Summit in the cases under consideration. Art 33(3) sets out the sanctions available in the case of arrears in paying membership dues, staggered according to the number of years that contributions are in arrears. It is arguable that these sanctions should also be available in instances of non-compliance with SADC Tribunal decisions. These measures include suspension of (i) the right to speak and receive documentation at meetings of SADC; (ii) recruitment, and renewal of contracts of employment, of personnel from the member State; (iii) SADC funds for new projects in the member State; and (iv) cooperation, between SADC and the member State, in the areas of cooperation spelt out in art 21 of the SADC Treaty (n 4). See Bartels (n 30) 45; Moyo (n 27) 610; Ruppel and Bangwamwabo (n 6) 201.

${ }^{89}$ See art 37 of the Protocol on Tribunal (n 5), which contains the procedures for amendment; see also Fritz (n 50) 2-3. 
natural persons against either States or the SADC itself. However, even if the number of inter-State disputes were to pick up, they would currently also remain in judicial limbo due to the suspension of the Tribunal. ${ }^{90}$ In fact, in addition to the SADC Treaty itself, most of the specialized Protocols that have been adopted within the SADC regime have been deprived of its sole mechanism for (inter-State) dispute resolution due to the suspension of the Tribunal. ${ }^{91}$

One of the remaining five thematic protocols which may still be able to engage in dispute settlement in the absence of the Tribunal, concerns the Protocol on Trade. ${ }^{92}$ Article 32 of this Protocol foresees a system of trade panels for the settlement of trade disputes between member States pertaining to the implementation and application of the Protocol. These panels, which are modelled on the WTO system for dispute settlement, are to be appointed and overseen by the Committee of Ministers responsible for trade matters. In case a trade panel is not able to settle a dispute, a referral to the Tribunal is possible as a last resort. ${ }^{93}$ Thus far, the dispute settlement system foreseen in the Protocol on Trade has remained unused. However, it is possible that as the pace of economic integration picks up in the region, so will the number of inter-State trade disputes and the need to resort to the dispute settlement system provided by the Protocol on Trade. If this were to happen, member States would currently have to rely exclusively on the trade panel system for the settlement of disputes, as referral to the Tribunal is impossible for as long as it remains suspended.

As far as human rights disputes are concerned, limited alternative mechanisms for dispute settlement on the regional level are available at present. The most prominent of these mechanisms are the African Commission and the African Court on Human and Peoples' Rights (hereinafter the African Court). All SADC members have ratified the African Charter, which provides for a monitoring body in the form of the African Commission. It may receive complaints concerning the violation of the African Charter from States against another State, or by individuals and non-governmental organizations (NGOs) against one or more State. ${ }^{94}$ The recommendations of the African Commission are non-binding.

At any time during its proceedings the African Commission can refer a case to the African Court in relation to those countries that have ratified the Protocol to the African Charter on Human and Peoples' Rights on the Establishment of an African Court on Human and Peoples' Rights ('the Protocol Establishing the Court'). Whereas the African Commission has jurisdiction over all States which have ratified the African Charter, the African Court only has jurisdiction over those African States which have-in addition-ratified the Protocol Establishing the Court. ${ }^{95}$ So although the African Court has the power to make binding

${ }^{90}$ Nicole Fritz, 'SADC Leaders Duplicitous in Axing Tribunal' Mail \& Guardian (Johannesburg 7-13 September 2012) 25.

${ }^{91}$ For a list of the extensive numbers of protocols and other specialized agreements, see <www.sadc.int/> and $<$ http://www.sadc-tribunal.org/pages/protocols.htm> accessed 28 November 2012.

${ }_{92}$ See $<$ www.sadc.int $/>$ accessed 28 November 2012.

${ }^{93}$ The Protocol on Trade of 24 August 1996, art 32 (1)-(6) <http://www.sadc-tribunal.org/docs/Trade.pdf $>$ accessed 28 November 2012.

${ }_{94}$ See African Charter (n 38) arts 48, 49 and 55; see also Centre for Human Rights, 'Celebrating the African Charter at 30: A guide to the African Human Rights System' (Pretoria University Law Press 2011) $4<$ http://www .pulp.up.ac.za/pdf/2011_13/2011_13.pdf> accessed 28 November 2012.

${ }^{95}$ See Protocol on the African Charter on Human and Peoples Rights on the Establishment of an African Court on Human and Peoples' Rights ('Protocol on the Establishment of the Court'), arts 5 and 34 <www.up.ac.za/chr> accessed 28 November 2012 . 
decisions,${ }^{96}$ the States subjected to its jurisdiction are much fewer in number than is the case with the African Commission. ${ }^{97}$

Currently, 26 of the 54 African States have ratified the Protocol Establishing the Court. These include only six of the SADC member States, namely, Lesotho, Mauritius, Mozambique, Malawi, South Africa and Tanzania. Two of these countries (Malawi and Tanzania) have also opted into an additional procedure provided for in Articles 5(3) and 34(6) of the Protocol Establishing the Court, in accordance with which individuals from these countries can bring claims directly before the African Court, as opposed to first resorting to the African Commission from where the case can then subsequently be referred to the African Court. However, for the purposes of this current article, the important factor is that merely 6 of the 15 SADC members have accepted the binding authority of the African Court in one form or another and individuals in the remaining nine States would not have any access to it. ${ }^{98}$

Moreover, an acute problem exists in relation to employees of the SADC which, for as long as the Tribunal remains inoperable, currently have no judicial protection against unfair labour practices. In this context, it is important to keep in mind that Article 31 of the SADC Treaty provides for immunity for the SADC and its institutions in the territory of the member States, comparable to those enjoyed by similar organizations under international law. Such immunity is generally regarded as necessary to ensure that international organizations can properly perform their functions. As a rule, the SADC would therefore be immune from litigation in member States, including litigation initiated by its own employees. ${ }^{99}$

However, it is important to point out, particularly in relation to employment disputes, that there has been a trend in recent years to waive the immunity of international organizations before domestic courts, if the organization in question failed to provide equivalent judicial protection for its staff members (such as, for example, through an independent tribunal within the organization). This development has notably been occurring in Europe under the influence of the Decision of the ECtHR in Waite and Kennedy $v$ Germany. ${ }^{100}$ In this case, employees of the European Space Agency (ESA) had initiated proceedings against the ESA in the German Labour Courts, as a result of a dispute concerning the employment contracts. The German Courts refused to provide the Plaintiffs legal protection on the ground that the ESA enjoyed immunity in the German courts in accordance with customary international law.

The Plaintiffs subsequently filed a complaint at the ECtHR, submitting that Germany violated its obligations to provide access to a fair hearing to individuals

96 See ibid art 30 .

97 The Court does, however, have a broad substantive jurisdiction. In accordance with Protocol establishing the Court (n 96) art 3(1), it may entertain cases and disputes concerning the interpretation and application of the African Charter, the Court's Protocol and any other human rights treaty ratified by the state concerned. See also 'Celebrating the African Charter' (n 94) 35.

98 These nine countries include Angola, Botswana, Democratic Republic of Congo, Madagascar, Namibia, Seychelles, Swaziland, Zambia and Zimbabwe. See also 'Celebrating the African Charter' (n 94) 35-6.

${ }_{99}$ See also Protocol on Immunities and Privileges (signed on 17 August 1992, entered into force 30 September 1993) art 1, available at <http://www.sadc.int/documents-publications/show/805> accessed 28 November 2012 . For a discussion of the immunities of international organizations, see Riccardo Pavoni, 'Human Rights and the Immunities of Foreign States and International Organizations' in Erika de Wet and Jure Vidmar (eds), Hierarchy in International Law: The Place of Human Rights (Oxford University Press 2012) $78 \mathrm{ff}$.

100 Waite and Kennedy v Germany App No 26083/94, ECtHR (18 February 1999) <http://hudoc.echr.coe.int> accessed 28 November 2012. 
within its jurisdiction, as required by Article 6(1) ECHR. Although the ECtHR rejected the claim it underscored that the legal protection mechanisms within the organization in question (in this case the ESA) must be seen as a material factor in determining whether granting the ESA immunity from German jurisdiction is permissible under the ECHR. It was only because the standard of legal protection provided for by the administrative body of the ESA was in conformity with what was required by Article 6(1) ECHR, that the recognition of the ESA's immunity in German courts did not constitute a violation of the ECHR. ${ }^{101}$ The Waite and Kennedy Decision thus confirmed the responsibility of ECHR member States to secure the rights under the ECHR, also in instances where competencies had been transferred to international organizations such as the ESA. ${ }^{102}$

This Decision had a spill-over effect on the domestic courts of ECHR member States. In several subsequent cases, the domestic court in question waived the immunity of an international organization, because the organization did not provide for judicial protection for its staff members that conformed to the requirements of Article 6(1) ECHR. For example, in the case of Siedler v Western European Union, the Belgian Court of Appeal waived the immunity of the Western European Union (WEU), as the internal Appeals Commission of the WEU did not provide adequate judicial protection for its employees. ${ }^{103}$ Similarly, the French Court of Cassation rejected the immunity of the African Development Bank $(\mathrm{BAD})$ in a dispute concerning one of its former employees. The BAD only provided for an Appeals Commission whose decision could be rejected by its President, which did not amount to protection that would equal that of an independent court of law. ${ }^{104}$

Although this line of jurisprudence was developed by the ECtHR, it is likely to serve as persuasive authority for domestic courts in Southern Africa if and to the extent that they were confronted with similar disputes. It is only a matter of time before a disgruntled SADC employee seeks relief from a domestic court in one of the member States, given the current suspension of the Tribunal. All of these countries are parties to the African Charter and the ICCPR, which guarantee rights similar to those in Article 6(1) of the ECHR. ${ }^{105}$ It is therefore possible that a domestic court in Southern Africa could apply the reasoning of the Waite and Kennedy Decision by analogy, when considering its own obligations under the African Charter or the ICCPR and waive the SADC's immunity to ensure that its employees receive a fair hearing.

However, it is doubtful whether the waiving of immunity under these circumstances would constitute a viable alternative mechanism for dispute resolution in the long run. Although it could serve as an important warning signal to the SADC about the urgency for reviving the Tribunal, it would also position the domestic courts

\footnotetext{
101 See also Pavoni (n 99) 103.

102 See also Matthews $v$ United Kingdom App no 24833/94, ECtHR (18 February 1999) para $32<$ http://hudoc.echr coe.int $>$ accessed 28 November 2012.

103 Siedler v Western European Union, ILDC 53 (BE 2003), Brussels Labour Court of Appeal, (17 September 2003), ILDC 1625 (BE 2009) (Court of Cassation, 21 December 2009).

${ }^{104}$ African Development Bank v Degboe, ILDC 778 (FR 2005) (25 January 2005). The jurisdictional link was established through the French nationality of the employee. For additional decisions and discussion see Pavoni (n 99) 105-6.

105 See African Charter (n 38) art 37(1); International Charter on Civil and Political Rights (adopted 16 December 1966, entered into force $23 \mathrm{March}$ 1976) art 14(1), available at <http://www.unhcr.org/refworld/docid/3ae6b3aa0.html> accessed 28 November 2012.
} 
in a potentially unsustainable conflict with the SADC member States. In addition, different courts in different member States may come to different conclusions regarding the waiving of immunity, which would undermine legal certainty.

\section{CONCLUDING REMARKS}

In the final analysis the rise and fall of the Tribunal exposed the member States' lack of understanding of the legal implications of the SADC Treaty regime, as well as their scant respect for legal obligations-whether on the domestic or regional level. States in the region tend to enter into ambitious, western-modelled regimes for economic and political integration, without sufficiently reflecting on the legal implications resulting from a comprehensive and consistent application of the rules embodied in the treaty regime in question. While this behaviour may in part result from capacity deficits in member States in relation to the law of international organizations, it is also rooted in an endemic disregard for the rule of law as such. ${ }^{106}$ Most of the member States have a poor domestic track record in relation to human rights protection and judicial independence. If nothing else, the fate of the Tribunal has poignantly illustrated that States that systematically fail to accept the binding authority of their own domestic courts are also unlikely to respect any binding decision of an international Tribunal. ${ }^{107}$

Seen from this perspective, and with the vision of hindsight, one may question the wisdom of bringing the Zimbabwean land cases to a fledgling tribunal which had hardly had any opportunity to foster a culture of acceptance amongst member States. Had the Tribunal instead been allowed to deal with less controversial cases for a number of years, its credibility - and therefore its chances of survival-might have been bigger by the time it took on controversial human rights disputes. ${ }^{108}$

As it stands, the central pillar for dispute settlement within the SADC regime has been rendered inoperable in relation to all types of disputes, while very limited alternative avenues for dispute settlement are available. On 23 November 2012, two prominent NGOs had requested the African Court to issue an advisory opinion on the legality of the suspension of the Tribunal, including the unilateral termination of office of its duly elected President and the refusal to reappoint or replace the judges whose terms of office have expired. ${ }^{109}$ The African Court may be approached for an advisory opinion by a broad variety of actors on the continent and may give an advisory opinion on any relevant human right instrument. ${ }^{110}$ At the heart of this dispute are the principles of equality before the law, access to justice (including the right to challenge the alleged violation of a fundamental right) and the independence of the judiciary as guaranteed in the

\footnotetext{
106 Ruppel and Bangwamwabo (n 6) 215.

107 Nathan (n 12) 133. The 2012 Freedom House Report < http://www.freedomhouse.org/report-types/freedom -world > accessed 28 November 2012, described only four of the member States as 'free', ie Botswana, Mauritius, Namibia and South Africa. Lesotho, Madagascar, Malawi, Mozambique, the Seychelles, Tanzania and Zambia were classified as 'partly free', while Angola, the Democratic Republic of Congo, Swaziland and Zimbabwe were classified as 'not free'. In a climate where only 4 of the 15 member classified as free, it is not possible to give effect to judicial independence.

108 Fritz (n 50) 4

109 In the Matter of a Request by the Pan African Lawyers Union (PALU) and Southern African Litigation Centre (SALC) for an Advisory Opinion Before the African Court on Human and Peoples' Rights, 23 November 2012 (document obtained at the courtesy of SALC and on file with author).

${ }^{110}$ See Protocol on the Establishment of the Court (n 95) art 4.
} 
African Charter. ${ }^{111}$ At the time of writing, the African Court had accepted the request for an advisory opinion, but still had to determine the date(s) of the hearing. Although non-binding in nature, an advisory opinion constitutes a persuasive legal determination of the matter at hand. A determination of unlawfulness of the suspension of the Tribunal would exert some pressure on the member States, but whether this will suffice to revive the Tribunal remains to be seen. ${ }^{112}$

111 African Charter ( $\mathrm{n}$ 38) arts 3, 7 and 26. In addition, the African Court will have to determine whether the procedures for appointing judges to the Tribunal in arts 3, 5, 7 and 8 of the Protocol on the Tribunal (n 5) have been violated. See In the matter of a request by PALU and SALC (n 109) 8-9.

112 See Richard Lee, 'Southern Africa: Court Asked to Rule on SADC Tribunal' All Africa (26 November 2012) $<$ http://allafrica.com/stories/201211270066.html> accessed 28 November 2012. 